\title{
Impact of COVID-19 on the economic-financial health of the company REIPROACERO S. A., during the periods 2019-2020
}

\section{Impacto del COVID-19 en la salud económica-financiera de la empresa REIPROACERO S. A., durante los periodos 2019-2020}

\author{
MUÑOZ-WALTER, Keily Jannina† \& SOTO-GONZÁLEZ, Carlos Omar
}

Universidad Técnica de Machala, Ecuador.

ID $1^{\text {st }}$ Author: Keily Jannina, Muñoz-Walter / ORC ID: 0000-0002-5650-5716

ID $2^{\text {nd }}$ Co-author: Carlos Omar, Soto-González / ORC ID: 0000-0001-5199-9246

DOI: $10.35429 / J I E C .2021 .9 .5 .1 .10$

Received July 10, 2021; Accepted December 30, 2021

\begin{abstract}
This research article focused on evaluating the economicfinancial situation of the company REIPROACERO SA, through the application of financial analysis methods and financial ratios, in order to determine the impact caused by the COVID-19 pandemic. On the other hand, within the investigative process the scientific method is applied, since it allowed to have an approach to the fact of interest, having contact with the data and information and real facts, which provided clues for the formulation of hypotheses and antecedents, building knowledge and leading to the verification of the same. Likewise, the qualitative descriptive approach was used, since the Financial Statements of the company, obtained from the Superintendencia de Compañias, Valores y Seguros, were analyzed; with a documentary design because information was obtained from scientifically recognized sources such as journals, articles in order to scientifically strengthen research. Where the results obtained showed excessive liquidity, low profitability and poor portfolio rotation.
\end{abstract}

Financial analysis, Financial statements, Economic and financial situation

\begin{abstract}
Resumen
El presente artículo de investigación se enfocó en evaluar la situación económica- financiera de la empresa REIPROACERO S.A, mediante la aplicación de métodos de análisis financiero y ratios financieros, para que de esa manera poder determinar el impacto que provoca la pandemia por el COVID-19. Por otra parte, dentro del proceso investigativo se aplica el método científico, ya que permitió tener un acercamiento al hecho de interés, teniendo contacto con los datos e información y hechos reales, los cuales proporcionaron pistas para formulación de hipótesis y antecedentes construyendo conocimientos y conduciendo a la verificación de las mismas. Así mismo se utilizó el enfoque cualitativo descriptivo, ya que se analizó los Estados Financieros de la empresa, obtenidos de la Superintendencia de Compañías, Valores y Seguros; con un diseño documental porque se obtuvo información de fuentes reconocidas científicamente como revistas, artículos con la finalidad de fortalecer científicamente investigación. En donde en los resultados obtenidos se evidencio una excesiva liquidez, baja rentabilidad y una rotación de cartera deficiente.
\end{abstract}

Análisis financeiro, Estados financeiros, Situación económica y financiera

Citation: MUÑOZ-WALTER, Keily Jannina \& SOTO-GONZÁLEZ, Carlos Omar. Impact of COVID-19 on the economicfinancial health of the company REIPROACERO S. A., during the periods 2019-2020. Journal- International Economy. 2021. 5-9:1-10.

$\dagger$ Researcher contributing first Author. 


\section{Introduction}

Financial analysis plays an indispensable role in the development of the activities of an entity, since it allows determining the health or the state in which the organization is in the economic and financial field, since from the result obtained from the analysis managers can make decisions either corrective or preventive, and even investment, also allows providing more reliable information to internal and external users (Paredes et al., 2019).

At the end of 2019 the world was affected by a virus that destabilized in several aspects, starting with health and therefore the global and family economy, as most governments chose to take preventive measures to avoid the spread of the virus, such as confinement. This directly affected the economic, social, technological and even political dynamization, which had an impact on the development of the activities of both companies and society in general, causing a drastic decrease in demand, income and labor, as well as difficulties in accessing financing, which was not foreseen in the strategic planning of any entity (Cevallos-Palma et al., 2020).

This study focuses on analyzing the impact of COVID-19 on REIPROACERO S.A., a company that has not been oblivious to the economic imbalance suffered by everyone, for which a comparison will be made through financial analysis, using financial analysis methods and financial indicators or ratios. Specifically, the reduction of its revenues is identified, evidently due to the abrupt decrease in demand, leading managers to reduce their staff, these are some of the effects that show the economic and social impact caused by the pandemic in the business environment.

Therefore, the objective of this article is to evaluate the economic-financial situation of the company REIPROACERO S.A., through the application of financial analysis methods and financial ratios, to determine the impact caused by COVID-19.
In such a way that the procedure of this research is composed of a summary, which is responsible for communicating quickly and concretely the content of the research, then the key words are described, the introduction, which highlights the importance of the work and where it is intended to reach, then is the development where the theoretical basis is conceptualized through the literature review, and then move to the results where the solution to the problem is demonstrated, and then end with the conclusions where the fulfillment of the objective or purpose of the research is expressed.

\section{Development}

\section{Financial Management}

Financial management is focused on all types of companies, since it fulfills the function of determining the financial part to cover in a timely manner all its activities or operations, where it also seeks to optimize to the maximum all resources, same that are indispensable for managers to make accurate decisions from the evaluation and analysis of financial information, in such a way that helps the fulfillment of the objectives of the entity in an efficient manner (Cabrera-Bravo et al., 2017).

\section{Financial administration}

Financial management is a science that facilitates the supply of economic resources in business transactions and investments that are needed within the organization, then the operation will be carried out efficiently and effectively (Ceballos et al., 2016).

\section{Financial Statements}

Financial Statements are defined as the mirror where it shows all the activities or operations of an entity in a given period, which can be quarterly, half-yearly or annual, so they are of vital importance within a company, because around the information they provide most of the decisions that managers make are based, as well as provide such information to external users in a reasonable reliable way, for which its structure must be composed according to the International Financial Reporting Standards (IFRS) and International Accounting Standards (IAS 1) (Perea et al., 2016). 
Within the main Financial Statements used to determine the economic-financial health are the Income Statements is the one that determines whether within the period has been obtained losses or gains within the same, it is structured by income and expenses (Elizalde, 2019). Likewise, another tool within this analysis is the Statement of Financial Position or also called Balance Sheet, it is that which is responsible for determining the entity's ability to cover its short and long term obligations, fulfilling the purpose of establishing control over operations to then determine the possible benefits that these may generate in the future, this statement is structured by three components: assets, liabilities and equity (Ruíz, 2017).

\section{Financial analysis}

The financial analysis is a set of technical procedures that allow determining the current economic-financial health of the entity, as well as allowing forecasting the situation in the future. This analysis is performed based on the information provided in the Financial Statements, through the study and interpretation performed by experts in the area, providing timely and efficient information to internal and external users (Saldaña \& Guamán, 2019).

\section{Financial analysis methods}

This method is composed of two types:

- Vertical Analysis: it is a static method or technique due to the fact that it is taken into account to evaluate the economic and financial health of an entity, the result of this calculation is expressed as a percentage and denotes what an account represents within a given group (Puerta et al., 2018).

Vertical anal $=\left(\frac{\text { Minor account }}{\text { Major account }}\right) * 100$

- Horizontal Analysis: This method of financial analysis that by means of an absolute variation calculates the increase or decrease of an accounting account, and the result is called relative variation and this is expressed as a percentage, it can be measured from one or more fiscal periods (Soto et al., 2018).

$V A=$ Year $1-$ Year 0
$V R=\frac{V A}{\text { Year } 0} * 100$

\section{Financial Indicators}

Also called financial ratios are a tool that is responsible for measuring the economic and financial situation of an entity, where it makes a comparison between historical and current information, so that from its results managers make decisions necessary for the development of the company, among the main financial ratios are, indicators of liquidity, activity, indebtedness and profitability (Correa-Garcia et al., 2018).

\section{Liquidity Indicators}

These are ratios that are responsible for calculating the capacity that the entity has to cover its short-term obligations or also called current liabilities, where the company seeks to convert its current assets into cash (Jara et al., 2018).

Among the main liquidity indicators are:

- Working Capital: This financial ratio establishes if the company has cash available to settle short-term debts, then the payment condition will be reflected, in the case that current assets exceed current liabilities the ratio will be very favorable (Fontalvo et al., 2011).

- Current Ratio: This indicator that establishes the sufficiency that the entity has to settle or cover the current obligations it has in the short term, whose cases are necessary of immediate payment or cancellation, that is to say that part of the assets can cover these debts, where it will determine whether the company can continue to operate or should be closed (Gutiérrez \& Tapia, 2016).

- $\quad$ Fast ratio: This is one of the indicators widely used when evaluating the liquidity of a company, it reflects the monetary supply to respond at any time to the shortterm commitments available to the entity (Fontalvo et al., 2011). 


\section{Activity indicators}

These indicators have the capacity to fulfill a certain function with its assets within the company, i.e. in accordance with the speed in which these values incurred in the same can be recovered (Espinoza et al., 2017).

\section{Where we can detail the following:}

- Rotation of accounts receivable: this index indicates the number of times that the collection of the commercialization of goods or services granted on credit is proceeded in a given fiscal period, the collection ability by the entity will be exposed (Gutiérrez-Calle et al., 2020).

- Average collection period: Expresses the time taken by the entity to collect the amounts that have not yet been paid in full by customers, i.e. the time is established in the days used to recover the portfolio (Gutiérrez-Calle et al., 2020).

- Inventory turnover: Through the inventory turnover index, the frequency with which the inventory is restored in a fiscal period is demonstrated, regardless of whether the transaction was made in cash or credit, for the respective calculation, the costs of goods sold are taken into consideration as part of the numerator and the average inventory as the denominator (Suárez \& Cárdenas, 2017).

- $\quad$ Average inventory age: This ratio allows determining the period of time that the company needs to be able to market its inventory, this with the purpose of being able to satisfy without inconvenience the needs of its customers, this time is expressed in days (Ureña, 2017).

- Average operating cycle: This is a financial indicator that shows the days it takes the company to recover its portfolio, i.e. the time it takes the entity to cash its accounts receivable once its obligations with third parties have been settled (Sanjines, 2019).

\section{Indebtedness indicators}

The purpose of this type of indicator is to evaluate the level of debt that the company has for its operation, then it will reflect the percentage of participation of creditors for the monetary contribution, in turn the risk that the owners maintain when resorting to subjects outside the business for financing, as is the case of financial institutions (Restrepo \& Sepúlveda, 2016).

- Debt ratio: It is recognized as indebtedness over assets because it represents the level at which assets are maintained under the contribution of third party sources, the calculation corresponds to the comparison of total liabilities between total assets (Salazar-Mosquera, 2017).

- Debt/equity ratio: it is also distinguished as indebtedness over equity, it determines the percentage that equity depends on creditors through the ratio between total liabilities and total equity (SalazarMosquera, 2017).

\section{Profitability indicators}

This indicator helps to quantify the competition that a financial institution has, the same that seeks the way or the opportunities that can be presented to achieve economic growth as well as within the market, this has many possibilities, however, everything depends on the strategies that each of the companies apply, whose purpose is to have a good performance of its assets and equity achieving positive results that favors the entity (Espinoza et al., 2017).

This is divided as follows:

- $\quad$ Gross profit margin ratio: Known as gross margin, this indicator shows the income obtained from sales after deducting the respective cost (Puente-Riofrío \& Andrade-Domínguez, 2016).

- $\quad$ Operating profit margin ratio: By means of this indicator, it is established whether the company is profitable or not without considering the contribution by financial means, then it is the portion of profit obtained from sales when discounting operational costs and expenses (Fontalvo et al., 2012). 
- Net profit margin ratio: This financial indicator indicates the profit or loss in its entirety because costs, expenses and taxes incurred in relation to net sales are deducted (Fontalvo et al., 2012).

- $\quad$ Ratio of profit on investment in assets: By means of this profitability indicator, the profits achieved by the management of assets are revealed, the calculation consists of the quotient of net profit between total assets (Cristobal, 2018).

- Ratio of profit over equity: Through this financial index it is possible to examine the portion of profit that corresponds to the partners with respect to what they have allocated for the development of the entity, for the calculation net profit and equity are required (Salazar-Mosquera, 2017).

\section{Methodology}

To diagnose the economic and financial situation of the company REIPROACERO S.A, the scientific method will be applied, since it allows us to have an approach to the fact of interest, likewise this method allows us to have contact with data and information and real facts, which provide clues to formulate hypotheses and background for the construction of knowledge and leads to the verification of the previously established hypotheses (Rodríguez \& Pérez, 2017).

Likewise, the approach to be used is the descriptive qualitative one, where the analyst makes a thorough measurement of its variables, based on objectives that are previously defined and delimited, so the Financial Statements of the company REIPROACERO S.A, obtained from the Superintendence of Companies, Securities and Insurance will be analyzed through the application of the methods of financial analysis and the financial ratios or indicators (CoronaLisboa, 2016).

In turn, a documentary design will be chosen because information will be extracted from scientifically recognized sources such as journals, articles with the purpose of scientifically strengthening the present research.
Taking into account that this design allows evaluating and analyzing the information in an objective, methodological and quantitative way, in such a way that allows making valid and reliable deductions (Cadena-Iñiguez et al., 2017).

\section{Results}

\section{Horizontal analysis}

To measure the impact caused by the COVID-19 in the company REIPROACERO S.A. the methods of financial analysis were used, the horizontal analysis to the Income Statement of the company REIPROACERO S.A., in the sales item in the year 2019 a total of $\$ 7.820 .876,49$, while for 2020 shows a total of $\$ 6.939 .410,86$, thus obtaining a decrease of $\$ 881.465,63$, which constitutes a $-11,27 \%$. Likewise, as for the operating expenses for the year 2019 it shows a total of $\$ 870,322.70$, while for the year 2020 $\$ 703,855.48$; having a decrease of $\$ 166,467.22$, which constitutes a $-19.13 \%$. In the year 2019 the company obtained a net profit of $\$ 196,468.01$, while for the period 2020 it obtained a net profit of $\$ 52,789.57$; having a decrease with respect to the previous year of $\$ 143,678.44$, same that represents $-73.13 \%$; this because its income decreased and its expenses increased, in the item of commissions increased by $749.73 \%$, likewise in taxes and eviction with $484.98 \%$ and $205.79 \%$ respectively.

The horizontal analysis shows that in the Statement of Initial Situation in 2019 the entity has total assets of $\$ 7,327,275.58$; while in 2020 it has total assets of $\$ 7,264,946.60$, with a decrease of $\$ 62,328.98$, which represents $0.85 \%$. On the other hand, liabilities in 2019 show a total of $\$ 5,003,344.89$, while for the following period a total of $\$ 4,893,651.73$; evidencing a decrease of $\$ 109,693.16$, which represents $-2.19 \%$. Likewise, the Equity for the period 2019 has a total of $\$ 2,323,930.69$, while for 2020 it has a total of $\$ 2,371,294.87$, showing an increase of $\$ 47,364.18$, which represents $2.04 \%$ between both periods.

\section{Vertical analysis}

On the other hand, regarding the vertical analysis to the Income Statement in the period 2019, it is evident that the item that has the highest representation is the Cost of Sales with $84.93 \%$ while in the year 2020 it is $88.66 \%$ over the total sales.

MUÑOZ-WALTER, Keily Jannina \& SOTO-GONZÁLEZ, Carlos Omar. Impact of COVID-19 on the economic-financial health of the company REIPROACERO S. A., during the periods 2019-2020. Journal- International Economy. 2021 
Regarding the vertical analysis in the Statement of Financial Position, it was obtained that in 2019 in the Assets, the accounts with the highest representation are Accounts Receivable; Property, plant and equipment; and Inventories with $41.46 \%$; $36.23 \%$ and $15.98 \%$ respectively to the total Assets, while in 2020 the most representative accounts of the Assets are also Accounts Receivable with $26.68 \%$ over the total assets; Property, plant and equipment with $48.55 \%$ and Inventories with $14.24 \%$ over $100 \%$ of its assets. As for its Liabilities in 2019 the most representative accounts are non-current and current accounts payable with $41.08 \%$ and $12.25 \%$ respectively, while in 2020 the most representative items are non-current accounts payable with $37.65 \%$ and obligations with financial institutions with $9.31 \%$. On the other hand, in 2019 the most representative account in equity is the accumulated results with $53.28 \%$; coinciding with the following year with $52.98 \%$ of the total equity.

\section{Liquidity ratios}

The company REIPROACERO S.A in 2019 reflects a working capital of $\$ 2,699,895.15$, while for 2020 this decreased to $\$ 2,248,080.37$; although this shows a decrease for the following year, the entity does have the necessary capacity to develop its activities or operations after covering its short-term obligations. Regarding the Current Ratio for the year 2019 and 2020, it is evidenced that for each dollar (\$1) in current liabilities the entity has a current liquidity of $\$ 2.37$ and $\$ 2.54$ respectively to settle them, which means that the entity has sufficient liquidity to cover its short-term obligations. Meanwhile, the quick ratio reflects that for every $\$ 1$ in current obligations, the entity has $\$ 1.78$ in 2019 and \$1.83 in 2020, as shown in Table 1.

Likewise in terms of long-term liquidity the company REIPROACERO S.A has, for the year 2019 a $68.28 \%$ while for the year 2020 shows a $67.36 \%$ of its committed assets in relation to the obligations that the organization passes, so it reflects an efficient long-term solvency to cover its liabilities with the assets that the entity has, however it is necessary to make wise decisions regarding the level of indebtedness, i.e. to determine whether it is necessary or convenient to acquire new obligations, as shown in Table 2.

\section{Debt ratios}

The company REIPROACERO S.A for the year 2019 evidences a debt ratio of $68.28 \%$; that is to say that this is the percentage that the entity has committed its assets while for the period 2020 a $67.36 \%$, the debt level decreased which is favorable; while the debt/equity ratio for the year 2019 the entity has committed $215.30 \%$ of its equity, while for the following year (2020) shows $206.37 \%$, evidencing a decrease which is favorable for the company; as shown in Table 2.

\section{Activity ratios}

The company REIPROACERO S.A, in the activity indicators reflect that in the average accounts receivable for the year 2019 reflects $\$ 2,358,257.02$; while for the period 2020 shows $\$ 2,488,294.32$; as for the turnover of accounts receivable in the year 2019 shows a turnover of 1.99 times, for the following year reflects a turnover of 1.67 times, thus showing a slower turnover for this period. The average collection period in the period 2019 shows 183.43 days, while for the period 2020 reflects 218.13 days to recover its portfolio. The average inventory in the year 2019 reflects $\$ 1374420.03$, while in the period 2020 shows $\$ 1102738.14$; so in its inventory turnover for the period 2019 reflects a turnover of 3.4 times while for the year 2020 its turnover increased to 5.58 times. Likewise, the average inventory age for the year 2019 shows 107.42 days while for the following year it shows 65.42 days, where it reflects a decrease, which is favorable for the company, since its liquidity increases. The average operational cycle for the year 2019 reflects 145.43 days, time that the entity takes to convert its accounts receivable into cash, while for the period 2020 this decreased to 141.78 days, i.e. for this period the entity makes its accounts receivable faster, as shown in Table 3.

\section{Profitability ratios}

The company REIPROACERO S.A. shows a gross profit margin ratio for the period 2019 of $11.34 \%$; that is to say that for each dollar of sales the entity will have a gross profit of $(\$ 0.11)$, that is to say $11.34 \%$; while for the year 2020 it increased to $15.07 \%$. Likewise, the Operating Profit Margin Ratio for the year 2019 reflects $3.94 \%$, while for the period 2020 shows $1.19 \%$ of operating margin; it shows a decrease between both periods. 
Meanwhile, the net profit margin ratio for 2019 reflects $2.51 \%$ of profit after calculating employee profit sharing and taxes, while for the 2020 period it only obtained $0.76 \%$ of net profit. As for the ratio of profit over investment in assets for the period 2019 shows $2.68 \%$ for each dollar of investment in assets, while for the period 2020 it reflects $0.73 \%$. Finally, the ratio of profit on equity for the year 2019 shows that for each dollar of investment in equity, it obtained a profit of $8.45 \%$; while in the 2020 period it reflects a profit of $2.23 \%$; as shown in Table 4.

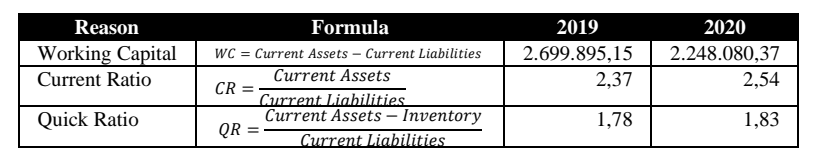

Table 1 Liquidity indicators

Source: Soto et al., (2018) and modified by the author

\begin{tabular}{|l|c|c|c|}
\hline \multicolumn{1}{|c|}{ Reason } & \multicolumn{1}{|c|}{ Formula } & $\mathbf{2 0 1 9}$ & $\mathbf{2 0 2 0}$ \\
\hline Debt Ratio & $D R=\frac{\text { Total Liabilities }}{\text { Total Assets }} \times 100$ & $68,28 \%$ & $67,36 \%$ \\
\hline $\begin{array}{l}\text { Debt to Equity } \\
\text { Ratio }\end{array}$ & $R D / P=\frac{\text { Total Liabilities }}{\text { Total Assets }} \times 100$ & $215,30 \%$ & $206,37 \%$ \\
\hline
\end{tabular}

Table 2 Debt indicators

Source: Soto et al., (2018) and modified by the author

\begin{tabular}{|l|c|r|r|}
\hline \multicolumn{1}{|c|}{ Reasson } & \multicolumn{1}{c|}{ Formula } \\
\hline $\begin{array}{l}\text { Average } \\
\text { accounts } \\
\text { receivable }\end{array}$ & $A A R=\frac{\text { CC.Initial }+ \text { CC. Final }}{2}$ & $2.358 .257,02$ & $2.488 .294,32$ \\
\hline $\begin{array}{l}\text { Accounts } \\
\text { Receivable } \\
\text { Turnover }\end{array}$ & $R C C=\frac{\text { Credit Sales }}{\text { Average Accounts Receivable }}$ & 1,99 & 1,67 \\
\hline $\begin{array}{l}\text { Average } \\
\text { Collection } \\
\text { Period }\end{array}$ & $P P C=\frac{365 \text { days }}{\text { Accounts Receivable Turnover }}$ & 183,43 & 218,13 \\
\hline $\begin{array}{l}\text { Average } \\
\text { Inventory }\end{array}$ & $I P=\frac{\text { Beginning Inventory }+ \text { Ending Inventory }}{2}$ & 1374420,03 & 1102738,14 \\
\hline $\begin{array}{l}\text { Inventory } \\
\text { Turnover }\end{array}$ & $R I=\frac{\text { Cost of Sales }}{\text { Average Inventory }}$ & 3,40 & 5,58 \\
\hline $\begin{array}{l}\text { Average } \\
\text { inventory } \\
\text { age }\end{array}$ & $E P I=\frac{365 \text { days }}{\text { Inventory Turnover }}$ & 107,42 & 65,42 \\
\hline $\begin{array}{l}\text { Average } \\
\text { operating } \\
\text { cycle }\end{array}$ & COP $=\frac{P P C+E P I}{2}$ & 145,43 & 141,78 \\
\hline
\end{tabular}

Table 3 Activity Indicators

Source: Soto et al., (2018) and modified by the author

\begin{tabular}{|c|c|c|c|}
\hline Reason & Formule & 2019 & 2020 \\
\hline $\begin{array}{lll}\text { Gross } & \text { Profit } & \text { Margin } \\
\text { Ratio } & & \\
\end{array}$ & $=\frac{\text { GMUB }}{\text { Gross Profit on Sales }} \times 100$ & $11,34 \%$ & $15,07 \%$ \\
\hline $\begin{array}{l}\text { Operating Profit Margin } \\
\text { Ratio }\end{array}$ & $R M U O=\frac{\text { Operating Profit }}{\text { Sales }} \times 100$ & $3,94 \%$ & $1,19 \%$ \\
\hline Net Profit Margin Ratio & $\begin{array}{l}\text { RMUN } \\
=\frac{\text { Net Profit }}{\text { Total Assets }} \times 100\end{array}$ & $2,51 \%$ & $0,76 \%$ \\
\hline $\begin{array}{l}\text { Ratio of Profit on } \\
\text { Investment in Assets }\end{array}$ & $\begin{array}{l}\text { RUSIA } \\
=\frac{\text { Net Profit }}{\text { ATotal Assets }} \times 100\end{array}$ & $2,68 \%$ & $0,73 \%$ \\
\hline $\begin{array}{l}\text { Ratio of Profit on } \\
\text { Equity }\end{array}$ & $R U S P=\frac{\text { Cost of Sales }}{\text { Average Inventory }} \times 100$ & $8,45 \%$ & $2,23 \%$ \\
\hline
\end{tabular}

Table 4 Profitability indicators

Source: Soto et al., (2018) and modified by the author

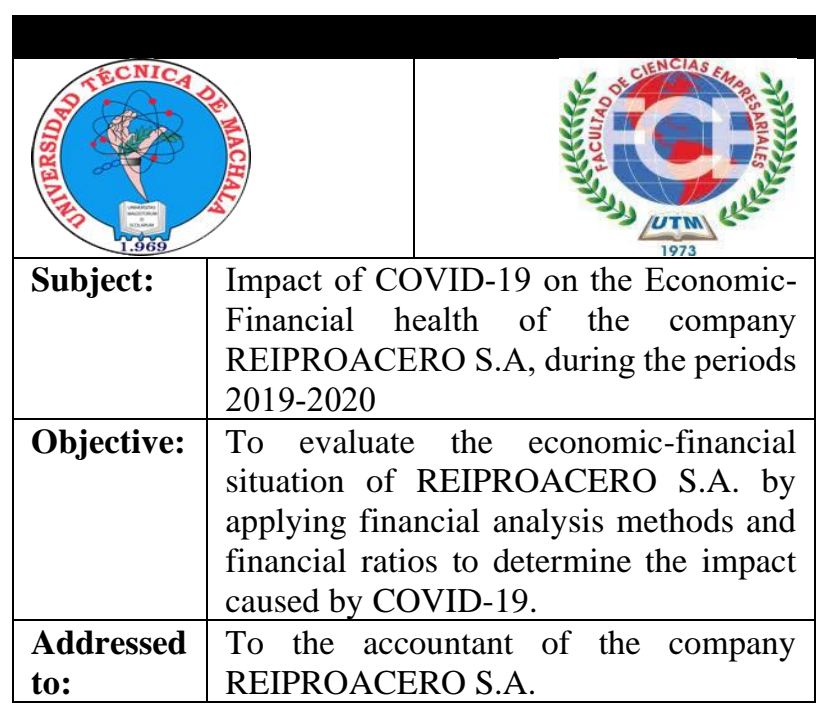

UNIVERSIDAD TÉCNICA DE MACHALA
"Calidad, Pertinencia y Calidez"

FACULTAD DE CIENCIAS EMPRESARIALES CARRERA DE CONTABILIDAD Y AUDITORIA INTERVIEW GUIDE

\section{GENERAL INFORMATION}

\begin{tabular}{|l|l|l|}
\hline \multirow{2}{*}{ Gender: } & \multicolumn{1}{|c|}{ Male } & Female \\
\cline { 2 - 3 } & \multicolumn{1}{|c|}{$\mathrm{X}$} & \\
\hline a) Age: & 32 \\
\hline b) Level of Education: & \\
\hline
\end{tabular}

\begin{tabular}{|l|l|l|l|}
\hline Basic & $\begin{array}{l}\text { High } \\
\text { School }\end{array}$ & University & Master's \\
\hline & & & \\
\hline & & & \\
\hline
\end{tabular}

c) Years of Labor Activity:

\begin{tabular}{|l|l|l|}
\hline $1-5$ years & $5-10$ years & $10-25$ years \\
\hline & & \\
\hline \multicolumn{2}{|l|}{ II. DEVELOPMENT }
\end{tabular}

1. Which financial analysis method do you apply?

\begin{tabular}{|l|l|}
\hline a) Horizontal Method & \\
\hline b) Vertical Method & $X$ \\
\hline c) Financial Indicators & \\
\hline d) All of the above & \\
\hline e) None of the above & \\
\hline
\end{tabular}

2. According to the previous answer, how often is the economic and financial situation of the entity evaluated?

a) Monthly

b) Bimonthly

c) Quarterly

d) Semiannual

e) Annual

3. According to your criteria, what is the economic and financial situation of the company compared to years before the COVID-19 crisis?

\begin{tabular}{|l|c|}
\hline a) Good & $X$ \\
\hline b) Bad & \\
\hline
\end{tabular}

Why? There was an unrestricted flow of suppliers and customers to the schedules.

4. Does the entity have a credit policy manual?

\begin{tabular}{|c|c|c|}
\hline \multicolumn{3}{|c|}{ a) Yes } \\
\hline \multicolumn{3}{|c|}{ b) No } \\
\hline \multicolumn{3}{|c|}{ 5. If yes, what is the percentage of credit sales? } \\
\hline \multicolumn{3}{|c|}{$60 \%$ of sales to fixed and constant customers. } \\
\hline \multicolumn{3}{|c|}{$\begin{array}{l}\text { 6. At what level does the use of financial analysis } \\
\text { influence decision making? }\end{array}$} \\
\hline a) & High & $\mathrm{X}$ \\
\hline b) & Medium & \\
\hline c) & Low & \\
\hline
\end{tabular}

MUÑOZ-WALTER, Keily Jannina \& SOTO-GONZÁLEZ, Carlos Omar. Impact of COVID-19 on the economic-financial health of the company REIPROACERO S. A., during the periods 2019-2020. Journal- International Economy. 2021 


\section{Conclusions}

Throughout the development of this research it was possible to demonstrate the importance of financial analysis within an entity, since this evaluates the economic and financial situation of the entity, in the case of the company REIPROACERO S.A. a comparison was made during the years 2019 and 2020, through the methods of financial analysis and financial indicators, which reflects the negative effects that the organization suffered because of the pandemic caused by COVID-19 and the following was obtained:

Through the horizontal financial analysis method it was shown that sales had a decrease of $11.27 \%$; consequently this transcends in the net profit of the period, this due to the paralysis of activities throughout the country caused by the aforementioned virus, since in its strategic planning such situation was not predicted; it was also analyzed through the vertical analysis where it was reflected that the most representative value in the years 2019 are the accounts and documents receivable with $41.46 \%$; This is due to the fact that the portfolio turnover is very slow, so it is recommended to evaluate the collection processes, so that in this way it can cover its obligations on time and reduce its accounts and documents payable, which for the year 2019 reflects $41.08 \%$, while for the period 2020 has $37.65 \%$, which may represent a conflict with suppliers and may affect the image of the entity.

As for the analysis through financial indicators, it was evidenced that the company REIPROACERO S.A for the year 2019 has an adequate liquidity, since it reflected $\$ 2.31$ to cover one dollar of its obligations, however, for 2020 it evidences \$2.54: same that is not adequate because it is outside the commonly acceptable ranges, this is because it has idle money, so it is recommended to invest such money to increase the productivity of the organization (Table 1). Likewise, regarding the activity ratios, it is evident that the accounts receivable turnover in 2019 is 1.99 times, while for the following period it is 1.67 times; therefore, it is evident that the portfolio recovery is very slow, taking into account the activity that the company is engaged in (Table 3 ). As for the indebtedness indicators, it was evidenced that the entity is within the acceptable ranges of financial obligations, having 68.28\% in 2019 and $67.36 \%$ in 2020 (Table 2).

ISSN-On line: 2524-2032

RINOE $^{\circledR}$ All rights reserved.
Finally, the profitability indicators for the period 2019 reflected a gross profit of $2.51 \%$, while for the following year $0.76 \%$; evidencing low profits for the entity (Table 4), so it should focus on putting corrective actions in the portfolio rotation and invest the money that is available once its obligations are paid (Table 3 ).

\section{References}

Cabrera-Bravo, C., Fuentes-Zurita, M., \& Cerezo Segovia, G. (2017). La gestión financiera aplicada a las organizaciones. Dominio de Las Ciencias, 3(4), 220-231. https://doi.org/10.23857/dom.cien.pocaip. 2017. 3.4.oct.220-232

Cadena-Iñiguez, P., Rendón-Medel, R., AguilarÁvila, J., Salinas- Cruz, E., De la Cruz-Morales, F., \& Sangerman- Jarquín, D. (2017). Métodos cuantitativos, métodos cualitativos o su combinación en la investigación: un acercamiento en las ciencias sociales. Revista Mexicana de Ciencias Agrícolas, 8, 1603-1617. https://www.redalyc.org/pdf/2631/2631535200 09.pdf

Ceballos, M., Cuastumal, B., \& Moreno, A. (2016). La Administración Financiera y la importancia del Presupuesto como base para el ahorro. 593 Digital Publisher, 79-97. https://www.593dp.com/index.php/593_Digital _Publisher/article/view/5

Cevallos-Palma, K. C., Bermeo-Pazmino, K. V., \& Vásconez-Acuña, L. G. (2020). Covid-19 y su impacto contable en las PYMES del cantón Cuenca. Revista Arbitrada Interdisciplinaria KOINONIA, V, 273-298. https://doi.org/http://dx.doi.org/10.35381/r.k.v5 i4.958

Corona-Lisboa, J. (2016). Apuntes sobre métodos de investigación. MediSur, 14, 81-83. http://scielo.sld.cu/scielo.php?script=sci_arttext \&pid=S1727-897X2016000100016

Correa-Garcia, J., Gómez-Restrepo, S., \& Londoño-Castañeda, F. (2018). Indicadores Financieros $\mathrm{Y}$ Su INDICADORES FINANCIEROS Y SU EFICIENCIA EN LA EXPLICACIÓN DE LA GENERACIÓN DE VALOR EN EL SECTOR COOPERATIVO*. Revista de La Facultad de Ciencias Económica: Investigación y Reflexión, XXVI(2), 129-144. https://doi.org/10.18359/rfce.3859

MUÑOZ-WALTER, Keily Jannina \& SOTO-GONZÁLEZ, Carlos Omar. Impact of COVID-19 on the economic-financial health of the company REIPROACERO S. A., during the periods 2019-2020. Journal- International Economy. 2021 
Cristobal, J. (2018). Caso de aplicación de análisis de estados contables: indicadores económicos y financieros para la toma decisiones en pymes. Ciencias Económicas, 75100. https://doi.org/10.14409/rce.v1i0.7748

Elizalde, L. (2019). Los estados financieros y las políticas contables. 593 Digital Publisher CEIT, 5-1(4), 217-226. https://doi.org/10.33386/593dp.2019.5-1.159

Espinoza, J., Gigueroa, I., \& Malavé, L. (2017). Rentabilidad financiera del Sector camaronero: Formulación del árbol de decisión mediante el algoritmo de CHAID. Revista de Negocios \& PyMES, 3(9), 27-34. https://ecorfan.org/spain/researchjournals/Nego cios_y_PyMES/vol2num5/Revista_de_Negocio s_\&_PYMES_V2_N5.pdf\#page $=41$

Fontalvo, T., Mendoza, A., \& Morelos, J. (2011). Evaluación del impacto de los sistemas de gestión de la calidad en la liquidez y rentabilidad de las empresas de la Zona Industrial de Mamonal (Cartagena-Colombia). Revista Virtual Universidad Católica Del Norte, 34 , 314-341. http://www.redalyc.org/articulo.oa?id=1942224 73015

Fontalvo, T., Vergara, J., \& De la Hoz, E. (2012). Evaluacion del impacto de los sistemas de gestion de calidad en la liquidez y rentabilidad de las empresas de la Zona Industrial Vía 40. Pensamiento \& Gestión, 32, 165-189.

http://rcientificas.uninorte.edu.co/index.php/pen samiento/article/viewFile/3361/2822\%0Ahttps:/ /dialnet.unirioja.es/servlet/articulo?codigo $=641$ 2681

Gutiérrez-Calle, J., Narváez-Zurita, C., TorresPalacios, M., \& Erazo-Álvarez, J. (2020). El examen especial y su incidencia en la gestión de la cartera de crédito en empresas comerciales. Dominio de Ciencias, 6, 127-166. http://dominiodelasciencias.com/ojs/index.php/ es/index

Gutiérrez, J., \& Tapia, J. (2016). Liquidez y rentabilidad. Una revisión conceptual y sus dimensiones. Revista de Investigación Valor Contable, 3(1), 9-32. https://doi.org/10.17162/rivc.v3i1.1229
Jara, G., Sánchez, S., Bucaran, R., \& García, J. (2018). Análisis De Indicadores De Rentabilidad De La Pequeña Banca Privada En El Ecuador a Partir De La Dolarización. Compendium, 5(12), 54-76.

https://dialnet.unirioja.es/servlet/articulo?codig $\mathrm{o}=6794253$

Paredes, C., Chicaiza, B., \& Ronquillo, J. (2019). Análisis financiero en las empresas del sector servicios en Ecuador entre los años 20162017. REVISTA DE INVESTIGACIÓN SIGMA, 06(2631-2603), 80-95. https://journal.espe.edu.ec/ojs/index.php/Sigma/ article/view/1676/0

Perea, S., Castellanos, H., \& Valderrama, Y. (2016). Estados financieros previsionales como parte integrante de un conjunto completo de estados financieros en ambiente NIIF. Una propuesta en el marco de la lógica difusa. Actualidad Contable Faces, 19, 113-141. https://www.redalyc.org/pdf/257/25744733006. pdf

Puente-Riofrío, M., \& Andrade-Domínguez, F. (2016). Relación entre la diversificación de productos y la rentabilidad empresarial. Revista Ciencia Unemi, 9(18), 73-80. http://repositorio.unemi.edu.ec/bitstream/12345 6789/3136/1/RELACIÓN ENTRE LA DIVERSIFICACIÓN DE PRODUCTOS Y LA RENTABILIDAD EMPRESARIAL.pdf

Puerta, F., Vergara, J., \& Huertas, N. (2018). Análisis financiero: enfoques en su evolución. Criterio Libre, 16(28), 85-104. https://doi.org/10.18041/1900-

0642/criteriolibre.2018v16n28.2125

Restrepo, A., \& Sepúlveda, C. (2016). Caracterización financiera de las empresas generadoras de energía colombianas (2005 2012). Revista Facultad de Ciencias Económicas, XXIV(2), 63-84. https://doi.org/10.18359/rfce.2213

Rodríguez, A., \& Pérez, A. (2017). Métodos científicos de indagación y de construcción del conocimiento. Revista Escuela de Administración de Negocios, 82, 175-195. https://doi.org/10.21158/01208160.n82.2017.16 47 
Ruíz, M. (2017). Preparación en normas internacionales de información financiera en las Pymes de Villavicencio - Colombia. Tendencias, XVIII, 27-44. https://doi.org/10.22267/rtend.171802.74

Salazar-Mosquera, G. (2017). Factores determinantes del desempeño financiero en el sector manufacturero en la República del Ecuador. Panorama Económico, 25(2), 243$254 . \quad$ https://doi.org/10.32997/2463-0470vol.25-num.2-2017-2076

Saldaña, C. X., \& Guamán, G. (2019). Análisis financiero basado en la técnica Fuzzy Logic, como instrumento para la toma de decisiones en la empresa Italimentos Cia. Ltda. Revista Economía y Política, $\quad X V(30), \quad 72-112$. https://doi.org/10.25097/rep.n30.2019.04

Sanjines, X. (2019). Aplicación de las razones financieras de actividad en una organización: Gestión y repercusiones en la liquidez [Universidad Técnica de Machala]. In Utmach. http://repositorio.utmachala.edu.ec/bitstream/48 000/13694/1/ECUACE-2019-CA-DE01066.pdf

Soto, C., Sanabria, S., \& Fajardo, M. (2018). Gestión Financiera Empresarial. In Revista Ecuatoriana de Investigaciones Agropecuaria (Issue 2). https://doi.org/10.31164/ceuta9789978978139

Suárez, G., \& Cárdenas, P. (2017). La rotación de los inventarios y su incidencia en el flujo de efectivo. Observatorio de La Economía Latinoamericana, $1-12$. http://www.eumed.net/cursecon/ecolat/ec/2017/ inventarios-flujo-efectivo.html

Ureña, E. (2017). EVALUACIÓN DE LA CONVERSIÓN Y GESTIÓN DE CUENTAS POR COBRAR E INVENTARIOS DE LA EMPRESA LA CASA DEL MUEBLE. In Utmach. http://repositorio.utmachala.edu.ec/bitstream/48 000/12906/1/ECUACE-2018-MKT-

DE00140.pdf 